\title{
A protoplasting technique with general applicability for molecular karyotyping of hymenomycetes
}

\author{
StePHEN LodDeR, ${ }^{* 1}$ DAVID WoOD ${ }^{2}$ and KeITH GulL ${ }^{1}$ \\ ${ }^{1}$ Department of Biochemistry and Molecular Biology, University of Manchester, Oxford Road, \\ Manchester M13 9PT, UK \\ ${ }^{2}$ Horticulture Research International, Worthing Road, Littlehampton, West Sussex BN17 6LP, UK
}

(Received 9 December 1992; accepted 28 January 1993)

\begin{abstract}
Pulsed-field gel electrophoresis (PFGE) has been used to facilitate genetic fingerprinting within a natural hymenomycete population. A protoplasting technique has been developed which shows that the basidial cells of the commercially important mushrooms Agaricus bisporus, A. bitorquis and Lentinus edodes (Shiitake), as well as from many wild growing Agarics, are sensitive to commercially available fungal cell wall degrading enzymes. The technique produces a high yield of intact protoplasts within short time periods. Using the basidial cell protoplasting technique, chromosomal-sized DNA from a wild fruit body of Coprinus comatus has been prepared and resolved into distinct bands using PFGE. This protoplasting technique will allow the application of PFGE to provide electrophoretic karyotypes within natural and commercial populations of hymenomycetes.
\end{abstract}

\section{Introduction}

Protoplast technology is used in fungal biology as a tool for several molecular biology, genetic and biochemical procedures. A number of recent advances in molecular genetics such as transformation and molecular karyotyping by pulsed-field gel electrophoresis (PFGE) (Peberdy, 1989), require the production of large numbers of protoplasts.

Among the fungi, the basidiomycetes include many commercially important edible species which could benefit from the application of molecular biology techniques for breeding programmes. The cultivated mushroom Agaricus bisporus is the most significant commercial mushroom. In the United Kingdom, it is the highest-valued protected crop, with over 70000 tonnes consumed annually, and has a world value in excess of $£ 2000 \mathrm{M}$ (Loftus et al., 1988). However, due to the complicated life cycle and slow growth of $A$. bisporus and other related species, progress in breeding and molecular techniques has been limited.

In the basidiomycetes, techniques for protoplast production have been based on those for model species such as Schizophyllum commune (De Vries \& Wessels, 1972). This has a shorter life cycle and faster growth and

*Author for correspondence. Tel (061) 275 5112; fax (061) 2755082.

Abbreviation: PFGE, pulse-field gel electrophoresis. can be cultivated on laboratory media. Protoplast production in this species makes use of fast-growing vegetative mycelia as a source material. In $A$. bisporus, however, the growth of sufficient mycelial biomass for protoplasting can take up to 8 weeks (Royer et al., 1991). This vegetative mycelium also shows unexplained differences in sensitivity to digestion by individual batches of wall-lytic enzymes, and even successful experiments often produce small amounts of protoplasts after extensive (up to $20 \mathrm{~h}$ ) incubation (Spear \& Royse, 1983).

Although the production of unicellular asexual spores, oidia, is the favoured source for protoplasts in the basidiomycete Coprinus cinereus (Binninger et al., 1987), natural extensive autolysis of sporophores during development in such basidiomycetes also produces protoplasts from gill tissue (Iten \& Matile, 1970; Moore, 1975). We have applied this approach to the fruit bodies of many basidiomycetes where the sporophores do not undergo extensive endogenous lysis. Gill tissue provides an easily obtained source of biomass. We show that this technique produces a high yield of protoplasts within short time periods, and that this method has general applicability to many hymenomycetes. Also we show that this technique produces protoplasts from naturally occurring hymenomycete sporophores, and these protoplast preparations can be used directly for electrophoretic karyotyping using PFGE. 


\section{Methods}

Strains. Agaricus bisporus sporophores of commercial strains Horst U3, S209 and A9, and A. bitorquis strain W2, were obtained from fruiting cultures grown at Horticulture Research International, Littlehampton. Sporophores of wild-growing Agarics from field samples were collected from parks in Manchester. The commercial mushroom Lentinus edodes was obtained from shops.

Protoplast preparation. Sporophores of $A$. bisporus and other species were harvested while the hymenium was still protected by a partial or universal veil, to reduce contamination of the gill surface. In A. bisporus, four or five freshly harvested sporophores $25-30 \mathrm{~mm}$ in diameter were used. Gill tissue at a stage prior to the formation of basidiospores was removed by dissection and approximately $2.0 \mathrm{~g}$ (wet wt) was placed into a sterile $15 \mathrm{ml}$ centrifuge tube containing $5 \mathrm{ml}$ of a filter-sterilized $10 \mathrm{mg} \mathrm{ml}^{-1}$ solution of Novozym 234 (Novo Labs) in MBS (0.6 M-sucrose dissolved in 0.05 M-sodium maleate buffer, $\mathrm{pH} 5.8$ ). Following incubation at room temperature for 20-30 min with gentle inversion, the mixture was filtered through glass wool to remove intact gill tissue from the protoplasts and centrifuged at $690 \mathrm{~g}$ in a swing-out bench centrifuge for $20 \mathrm{~min}$ at room temperature. The protoplast pellet was washed twice by resuspension in MBS prior to viewing under the microscope.

Protoplasts from naturally growing Agarics and the commercial mushroom $L$. edodes were produced in an identical manner to those from $A$. bisporus, except that only one sporophore was used from each of the naturally growing Agarics, due to their large size whilst still having a low number of basidiospores and an intact veil.

Fluorescent staining. Protoplasts were fixed in $25 \%$ (v/v) glutaraldehyde for $30 \mathrm{~min}$, washed and resuspended in distilled water. Nuclei were visualized by staining with $1 \mu \mathrm{g}$ (4,6-diamino-2-phenylindole dihydrochloride) (DAPI) $\mathrm{ml}^{-1}$, with $1 \mathrm{mg} p$-phenylenediamine $\mathrm{ml}^{-1}$ as an anti-fade agent, and observed using a Zeiss Axioskop microscope fitted with $\times 40$ and $\times 100$ neofluor lenses and a mercury-tungsten UV lamp along with a set of filters appropriate for DAPI fluorescence.

Calcofluor M2R NEW was used to determine whether protoplasts had residual cell walls. Unfixed protoplasts were resuspended in $500 \mu \mathrm{l}$ MBS containing $0.05 \%$ Calcofluor and viewed under fluorescence microscopy.

Pulsed-field gel electrophoresis. Protoplasts were diluted to a final concentration of $10^{8}-10^{9} \mathrm{cells} \mathrm{ml}^{-1}$ with MBS containing $0.8 \%$ low gelling temperature agarose (Sea Plaque; FMC corporation) at $37^{\circ} \mathrm{C}$ and dispensed into $20 \times 9 \times 1.2 \mathrm{~mm}$ moulds. The mixture was placed at $4{ }^{\circ} \mathrm{C}$ for $30 \mathrm{~min}$ to solidify. Blocks were incubated in NDS buffer (10 mM-Tris/HCl pH 9.5, 0.4 M-EDTA pH 8.0, $2 \%$ (w/v) $N$-laurylsarcosine, $1 \mathrm{mg}$ proteinase $\mathrm{K} \mathrm{ml}^{-1}$ ) at $50^{\circ} \mathrm{C}$ for $48 \mathrm{~h}$. Plugs were stored in NDS at $4{ }^{\circ} \mathrm{C}$. PFGE was performed using the BioRad CHEF DR II system. For chromosomal size markers, Candida albicans strain ASR 4 and Saccharomyces cerevisiae strain YP148 were electrophoresed along with chromosomal DNA from wild growing Agaric species at 12 ${ }^{\circ} \mathrm{C}$ in $0.5 \times$ TBE buffer (45 mM-Tris/borate, $5 \mathrm{mM}$-EDTA) on a $1.0 \%$ $(\mathrm{w} / \mathrm{v})$ agarose gel (molecular biology grade agarose, BioRad) dissolved in $100 \mathrm{ml} 0.5 \times \mathrm{TBE}$ buffer. Separation was achieved by using pulse intervals of $300 \mathrm{~s}$ for $24 \mathrm{~h}$ at $140 \mathrm{~V}$ and $1200 \mathrm{~s}$ for $48 \mathrm{~h}$ at $80 \mathrm{~V}$. Following electrophoresis, gels were stained in $0.5 \mu \mathrm{g}$ ethidium bromide $\mathrm{ml}^{-1}$ for $1 \mathrm{~h}$, destained for $2 \mathrm{~h}$ and photographed.

\section{Results}

Incubation of gill tissue in Novozym 234 resulted in rapid production of protoplasts, which readily underwent lysis when placed in distilled water. The basidial cells on the surface of the gill tissue from all of the Agaric species studied were sensitive to the lytic enzymes used (Fig. 1), with cell wall degradation occurring at the apex of the basidia after $5 \mathrm{~min}$. The basidial wall remained
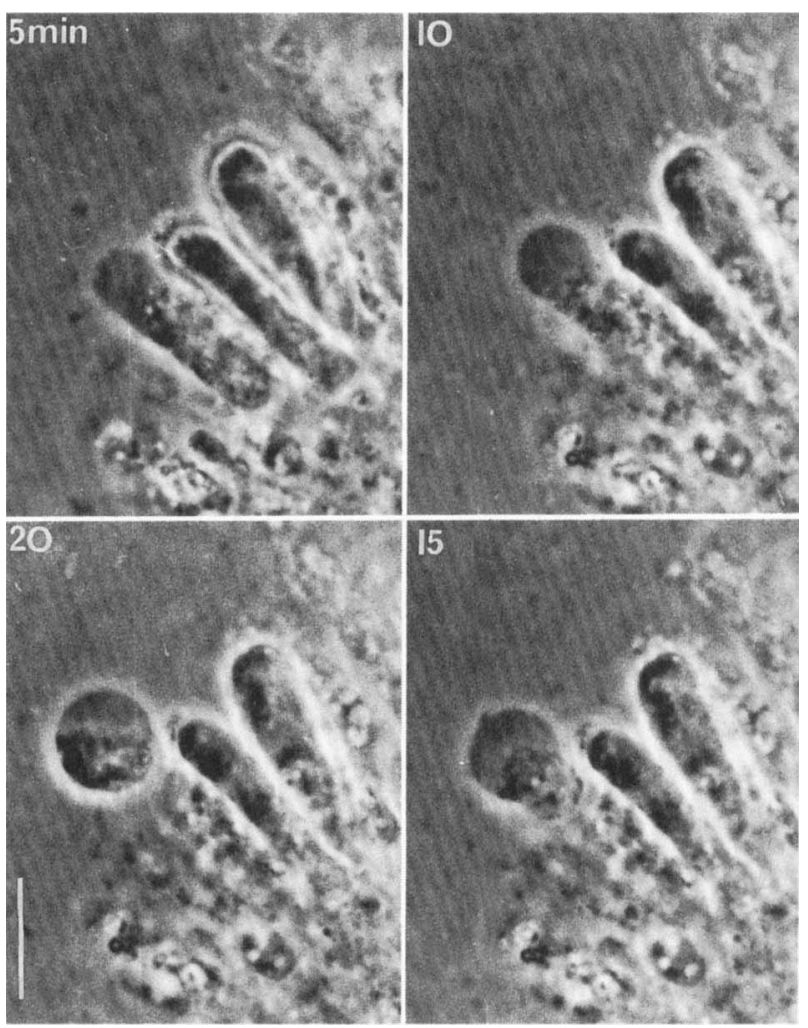

Fig. 1. Time-lapse photography showing the basidial cells of $A$. bisporus incubated in Novozym 234 with subsequent production of protoplasts. Bar, $10 \mu \mathrm{m}$.

Table 1. Protoplast yield from gill tissue from sporophores of commercial and wild-growing Agarics incubated in Novozym 234

\begin{tabular}{lc}
\hline \hline \multicolumn{1}{c}{ Agaric species } & $\begin{array}{c}10^{-7} \times \text { No. of } \\
\text { protoplasts } \\
(\mathrm{ml} \text { enzyme) }\end{array}$ \\
\hline Agaricus bisporus strain U3 & $205 \pm 28$ \\
A. bisporus strain U3† & $88 \pm 3$ \\
A. bisporus strain S209 & $195 \pm 19$ \\
A. bisporus strain A9 & $80 \pm 7$ \\
A. bitorquis strain W2 & $103 \pm 5$ \\
Lentinus edodes & $80 \pm 5$ \\
Armillaria mellea & $49 \pm 13$ \\
Coprinus comatus & $2 \pm 0.4$ \\
Lepiota procera & $13 \pm 2$ \\
L. rhacodes & $5 \pm 0 \cdot 9$ \\
Amanita muscaria & $0 \cdot 2 \pm 0.08$ \\
\hline \hline
\end{tabular}

* Means \pm SD.

† Yield obtained using the enzyme mixture Onozuka Cellulase plus chitinase. 

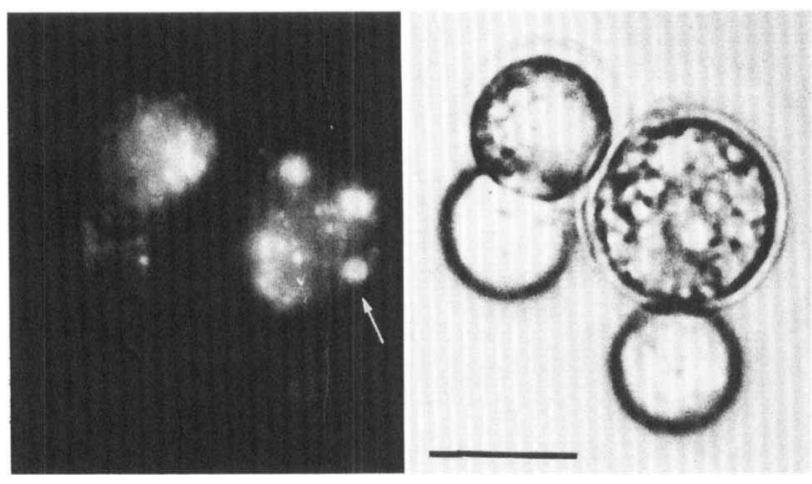

Fig. 2. Protoplasts of $A$. bisporus stained in DAPI to show nuclei (arrowed). Mitochondria appear as small dots in the cells. Bar, $10 \mu \mathrm{m}$.

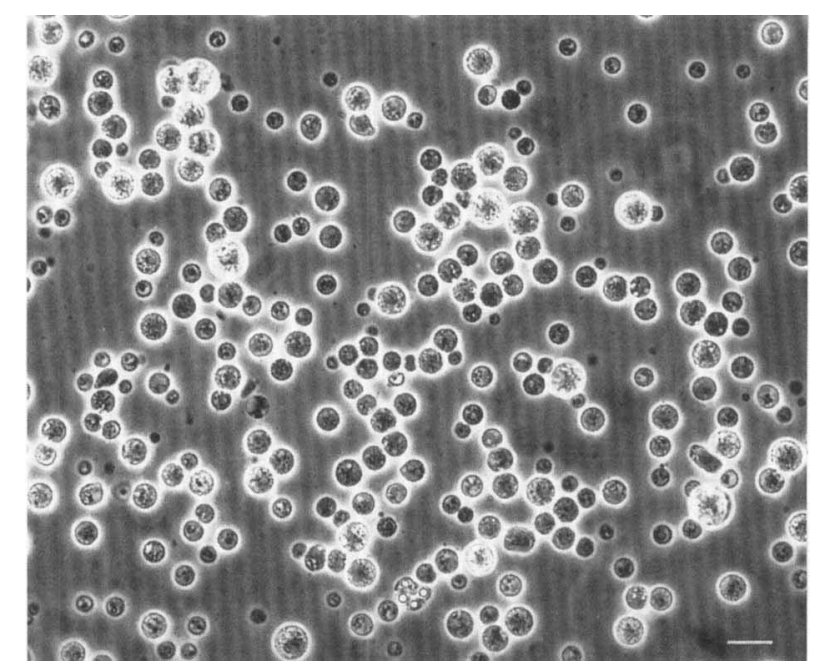

Fig. 3. Protoplasts of the naturally occurring Agaric Coprinus comatus produced by incubation of gill tissue in Novozym 234. Bar, $10 \mu \mathrm{m}$.

intact after liberation of the protoplast and it was assumed that the protoplasts were formed by the extrusion of cytoplasm through the open tip (Fig. 1). This was confirmed by the failure of the protoplasts to fluoresce when stained with the optical brightener Calcofluor, which has been used previously to show the presence of cell wall remnants (Gull et al., 1972; Sonnenberg et al., 1988). After 20-30 min incubation in enzyme the number of protoplasts from $A$. bisporus was in the order of $8.8 \times 10^{8}-2.0 \times 10^{9}$ protoplasts per $0.2 \mathrm{~g}$ dry wt of original gill tissue, with a similar high yield being found in many other Agaric species (Table 1).

All strains of the cultivated mushroom A. bisporus tested, strains of other commercially important mushrooms such as A. bitorquis and L. edodes, and several wildgrowing Agaric species readily produced protoplasts when dissected gill tissue was incubated in enzyme solution (Table 1). No batch-to-batch variation in the action of the commercial cell wall degrading enzyme was

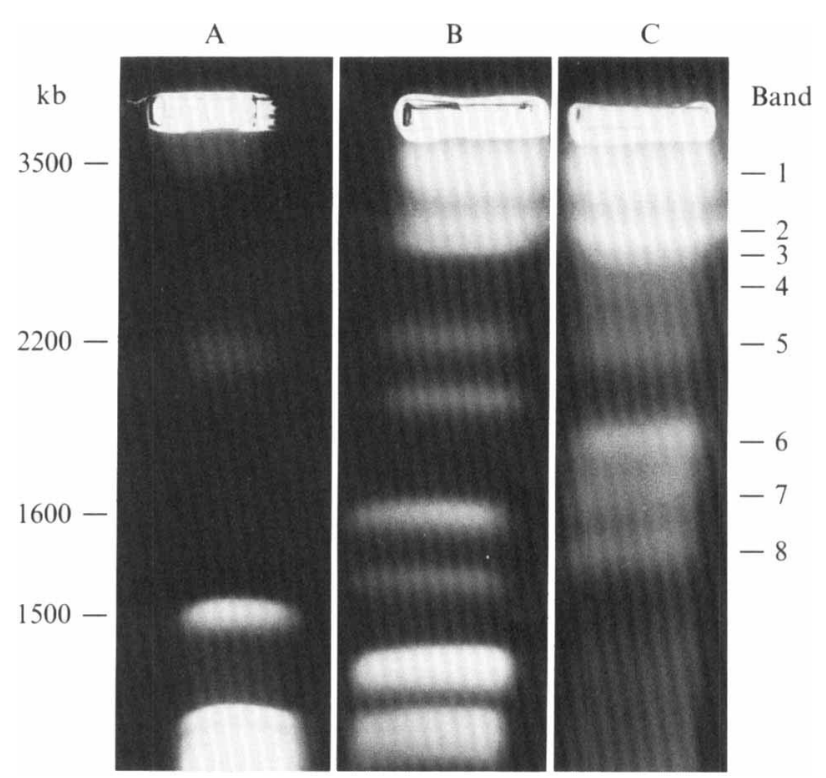

Fig. 4. Chromosomal-sized DNA of the wild-growing Agaric Coprinus comatus, separated by pulsed-field gel electrophoresis (lane C) compared with DNA from Saccharomyces cerevisiae (lane A) and Candida albicans (lane B).

seen. Five different batches of Novozym 234 were used, all of which produced a similar number of protoplasts within the same time period (data not shown). Other enzyme preparations were also tested for their ability to liberate protoplasts from the basidial cells of $A$. bisporus. Onozuka R-10 cellulase and chitinase were used to make protoplasts in Coprinus cinereus and C. bilanatus (Binninger et al., 1987; Burrows et al., 1990). This enzyme mixture was similar in effect to that of Novozym 234 in its protoplasting ability on the gill tissue of basidiomycetes (Table 1).

Protoplasts from A. bisporus were stained with DAPI, which allowed the number of nuclei in each cell to be observed (Fig. 2). Approximately $50 \%$ of all the protoplasts produced contained no visible nuclei, but of the remainder, the number of nuclei per protoplast ranged from one to four per cell. A similar number of nucleated protoplasts were seen in all the Agaric species observed (data not shown). The protoplasts produced were then used for electrophoretic karyotyping. Gillderived protoplasts produced from naturally occurring sporophores of $C$. comatus (Fig. 3) can be used as the starting material for analysis of molecular karyotypes of such organisms. Chromosomal-sized DNA was prepared from the fruiting bodies of wild-growing $C$. comatus, and separated into distinct chromosomal bands using PFGE (Fig. 4). At least eight chromosomal-sized DNA bands were seen. Using chromosome size markers it was possible to estimate the size of the individual chromosomal-sized DNA bands in C. comatus, which 
ranged from 1.4 to $3.5 \mathrm{Mb}$. A linear relationship has been shown to exist between ethidium bromide stain intensity and DNA concentration (Barton \& Gull, 1992). Differences in the fluorescence intensity of some of the DNA bands shown in Fig. 4 may suggest that co-migration of chromosomes has occurred. A single set of running conditions in which all bands can be routinely separated is not always achievable for many fungi, so further optimization of the running conditions by changing the pulse times and voltage may be needed to allow for a clearer separation of these closely associated bands. The generation of electrophoretic karyotypes of Lepiota procera and Amanita muscaria has also been attempted and has shown that chromosome-sized bands can be observed in these species.

\section{Discussion}

A substantial amount of literature already exists on techniques for protoplasting various groups of filamentous fungi (reviewed by Peberdy, 1979). Protoplasting protocols for use in the basidiomycetes, however, are often based on fast-growing easily cultivated 'model species'; but while protoplasts can be produced from the more difficult to grow ectomycorrhizal basidiomycetes (Barrett et al., 1989), the yields of nucleated protoplasts are often too low for use in molecular biological techniques such as PFGE, where large amounts of intact nuclear DNA are required (Kayser \& Wostemeyer, 1991).

The age of the fungal culture has been shown to play a critical role in protoplast formation (Peberdy, 1979). Actively growing mycelia are more susceptible to protoplasting enzymes than are slow-growing or older mycelia. The problem of slow-growing vegetative mycelia has hindered the production of a satisfactory protoplasting protocol in $A$. bisporus and the many wildgrowing Agaric species. A lower yield of protoplasts is also caused by batch-to-batch variability within the commercially available cell wall degrading enzymes. Some uniformity in enzyme action can be obtained by producing the enzymes in the laboratory, but this is time consuming and often impractical (Hamlyn et al., 1981).

Basidial cells are actively growing cells, differentiating into sterigmata and spores as the fruit body matures. In Coprinus it has been shown that protoplasts can be released from the gill tissue during self-autolysis (Moore, 1975), and that it is the basidial cells rather than the vegetative mycelium from which the protoplasts are produced (Schulz-Weddigen, 1982). In the cultivated mushroom A. bisporus and in all the other Agaric species that were examined here (Table 1), the basidia were susceptible to the action of enzymes, such as the commonly used Novozym 234 and the Onozuka Cellulase/chitinase combination, allowing subsequent high yields of proto- plasts. Batch-to-batch variation of the commercial enzymes used had no significant effect on the yield of protoplasts, suggesting that the actively growing basidial cells are very sensitive to chitinase activity, unlike vegetative cell walls, which require much longer incubation periods in the lytic enzymes (Spear \& Royse, 1983).

In previous protoplasting experiments using $A$. bisporus, the numbers of protoplasts obtained from vegetative mycelium varied from 1.0 and $2.0 \times 10^{7}$ protoplasts ( $\mathrm{g} \mathrm{dry} \mathrm{wt}^{-1}$ ) (Sonnenberg et al., 1988) using a laboratory-prepared enzyme mixture, to $5.0 \times 10^{8}$ to $2.0 \times 10^{9}$ protoplasts per $0.3 \mathrm{~g}$ dry wt (Royer et al., 1991) with the requirement for the generation of large amounts of actively growing mycelium taking up to 8 weeks to grow. The incubation of the vegetative mycelium in lytic enzyme is extensive, ranging from 3-4 h (Sonnenberg et al., 1988) to $20 \mathrm{~h}$ (Spear \& Royse, 1983). Using the basidial protoplasting technique the number of protoplasts produced ranged from $8.8 \times 10^{8}$ to $2.0 \times 10^{9}$ per $0.2 \mathrm{~g}$ dry wt. Sporophores were obtained from commercial mushroom growers and used immediately, and the incubation time of gill tissue in lytic enzymes was greatly reduced to $20-30 \mathrm{~min}$.

Interestingly, the basidial cell protoplasting technique can be applied to many of the wild-growing Agarics (Table 1), and electrophoretic karyotypes have been produced for a few of these species using PFGE. Previous attempts at using these wild-growing species in such studies have been prevented mainly by the biology of these organisms, many having specific nutritional or symbiotic relationships (i.e. mycorrhizal) which prevents their cultivation under laboratory conditions. Even the cultivated mushroom $A$. bisporus and closely related species are slow-growing on artificial media and are difficult to fruit in the laboratory.

This protoplasting technique facilitates the application of PFGE and other DNA-based technologies to provide electrophoretic karyotypes of these wild-growing and commercial mushroom species. This addition offers a substantial improvement on previous attempts at genetic fingerprinting using restriction fragment length polymorphism (RFLP) analysis on genomic DNA. In commercial populations of the cultivated mushroom, strains are phenotypically similar and have been described as being 'near monoculture' (Royse \& May, 1982), with RFLP patterns in A. bisporus showing infrequent differences (Summerbell et al., 1989; Allen et al., 1992). A similar situation exists in commercial Acremonium strains, where phenotype and RFLP analysis fails to discriminate between strains. However, genetic fingerprinting of the Acremonium strains could be obtained by using PFGE, where chromosomal variation was apparent (Walz \& Kuck, 1991). This protoplasting method lends itself to the analysis of genetic differences 
between natural and commercial populations of hymenomycetes using PFGE, and is likely to have other applications in transformation and genetic improvement of such fungi.

We wish to thank Tim Elliott and Mike Challen at HRI and Roger Gerke at Manchester for many useful discussions and suggestions. This study was supported by an SERC-CASE studentship.

\section{References}

Allen, J. J., Moore, D. \& Elliott, T. J. (1992). Persistent meiotic arrest in basidia of Agaricus bisporus. Mycological Research 96, $125-127$.

Barrett, V., Lemke, P. A. \& Dixon, R. K. (1989). Protoplast formation from selected species of ectomycorrhizal fungi. Applied Microbiology and Biotechnology 30, 381-387.

BARTON, R. C. \& GULL, K. (1992). Isolation, characterization, and genetic analysis of monosomic, aneuploid mutants of Candida albicans. Molecular Microbiology 6, 171-177.

Binninger, D. M., Skrzynia, C., Pukkila, P. J. \& Casselton, L. A. C. (1987). DNA-mediated transformation of the basidiomycete Coprinus cinereus. EMBO Journal 6, 835-840.

Burrows, B. M., Elliott T. J. \& Casselton, L. A. (1990). DNAmediated transformation of the secondarily homothallic basidiomycete Coprinus bilanatus. Current Genetics 17, 175-177.

DE VRIES, O. M. H. \& Wessels, J. G. H. (1972). Release of protoplasts from Schizophyllum commune by a lytic enzyme from Trichoderma viride. Journal of General Microbiology 73, 13-22.

Gull, K., Moore, P. M. \& TrincI, A. P. J. (1972). Preparation of protoplasts from Geotrichum lactis and use of fluorescence to detect cell walls. Transactions of the British Mycological Society 59, 79-85.

Hamlyn, P. F., Bradshaw, R. E., Mellon, F. M., Santiago, C. M., WiLSON, J. M. \& PEBERdy, J. F. (1981). Efficient protoplast isolation from fungi using commercial enzymes. Enzyme and Microbial Technology 3, 321-325.

ITEN, W. \& MATILE, P. (1970). Role of chitinase and other lysosomal enzymes of Coprinus lagopus in the autolysis of fruiting bodies. Journal of General Microbiology 61, 301-309.

KAYSER, T. \& WOSTEMEYER, J. (1991). Electrophoretic karyotype of the zygomycete Absidia glauca: evidence for differences between mating types. Current Genetics 19, 279-284.

Loftus, M. G., MOORE, D. \& ElliotT, T. J. (1988). DNA polymorphisms in commercial and wild strains of the cultivated mushroom Agaricus bisporus. Theoretical and Applied Genetics $\mathbf{7 6}$, 712-718.

MoORE, D. (1975). Production of Coprinus protoplasts by use of chitinase or helicase. Transactions of the British Mycology Society 65, 134-136.

Peberdy, J. F. (1979). Fungal protoplasts: isolation, reversion, and fusion. Annual Review of Microbiology 33, 21-39.

Peberdy, J. F. (1989). Fungi without coats - protoplasts as tools for mycological research. Mycological Research 93, 1-20.

Royer, J. C., Hintz, W. E. \& Horgen, P. A. (1991). Efficient protoplast formation and regeneration and electrophoretic karyotype analysis of Agaricus bisporus. In Genetics and Breeding of Agaricus, pp. 52-56. Edited by L. J. L. D. Van Griensven. Wageningen: Pudoc.

Royse, D. J. \& MAY, B. (1982). Use of isozyme variation to identify genotype classes of Agaricus brunnescens. Mushroom Science 8, 1-9.

SCHUlz-WeddigeN, I. (1982). Protoplasten aus Basidien und vegetativen Zellen von Coprinus radiatus. Berichte Deutschen Botanischen Gesellschaft 95, 431-440.

Sonnenberg, A. S., Wessels, J. G. H. \& Van Griensven, L. J. (1988). An efficient protoplasting/regeneration system for Agaricus bisporus and Agaricus bitorquis. Current Microbiology 17, 285-291.

SPEAR, M. \& RoYSE, D. J. (1983). Formation, purification, and regeneration of protoplasts from Agaricus brunnescens. Phytopathology 73, 375 .

Summerbell, R. C., Castle, A. J., Horgen, P. A. \& Anderson, J. B. (1989). Inheritance of restriction fragment length polymorphisms in Agaricus brunnescens. Genetics 123, 293-300.

WalZ, M. \& KuCK, U. (1991). Polymorphic karyotypes in related Acremonium strains. Current Genetics 19, 73-76. 